Accepted

24. 08. 2020

Revised

15. 09. 2020

Published

29. 10.2020

Keywords

constitution,

constitutional

principles and

norms,

accessibility and

quality of

medical

care

problems of

realization of the

right to

health

protection,

prospects for the

development of the

right to

health

protection.

\section{The Constitutional Right to Health PROTECTION IN BELARUS}

\author{
AKSANA SHUPITSKAYA \\ Yanka Kupala State University of Grodno, Faculty of Law, Grodno, Republic of \\ Belarus. \\ E-mail: oshupitskaya@mail.ru, oshupitskaya@grsu.by \\ CORRESPONDING AUTHOR \\ oshupitskaya@grsu.by
}

Abstract The article analyzes the constitutional right enshrined in the Fundamental law of the Belarusian state, its Constitution, - the right to health protection. The purpose of the research is to analyze the relevant legal regulations and the problems associated with implementing the right to health protection in the modern Belarus. The paper will examine the constitutional basis of the right to health protection in Belarus, its essence and nature, normative legal acts regulating the analyzed right, problems and prospects of its implementation in light of the current conditions of the Belarusian state. The author considers the constitutional legal principles and constitutional legal norms as the basis of the right to health protection and reveals the essence of the analyzed right. The conclusion substantiates the idea that detailed regulation of the right to health protection is carried out at the level of normative legal acts of the Republic of Belarus adopted by various state bodies. The state of realization of the right to health protection is determined by socio-economic, political and other factors. Identifying a number of problems related to ensuring the right to health protection, the researcher analyzes the prospects for its further development in the Republic of Belarus. 


\section{$1 \quad$ Introduction}

In the legal science of the post-soviet states, the constitutional right to health protection was considered from both theoretical and practical perspectives. Such well-known legal theorists and constitutionalists as Avakian, Alekseev, Bernatsky, Baglay, Bondar, Vitruk, Voevodin, Gadzhiev, Liverovsky and others analyzed this right from a constitutional, rather than merely legislative, perspective. Specialists in the field of medical law Alexandrova, Gerasimenko, Kovalevsky, Litovka, Litovka, Maleina, and Khabrieva also made significant contributions to the study of the analyzed issues. Among the most famous theorists that studied the right to health protection are Alexandrova (Alexandrova, 2006), Azarov (Azarov, 2007), and Timofeev (Timofeev, 2017).

The right to health protection is one of the subjective rights that is not recognized by all countries, and therefore is not established in their most important legal acts, usually their constitutions. Instead, it is regulated at the international level by various legal documents and is implemented in practice through the activities of international legal jurisdictional institutions. In particular, as Murgel states, although the European Court of Human Rights does not explicitly regulate the right to health, it considered the right to health in cases that included alleged violations of the rights guaranteed by the ECHR. In some cases, the Court interpreted the ECHR in a way that the Contracting States should also provide the right to health care to the applicant. Some of these cases concerned the responsibility of medical professionals for medical error (Murgel, 2020: 22).

The right to health protection is an important constitutional right enshrined in the fundamental law of the Belarusian state. The constitution also refers to socioeconomic rights and freedoms. The Constitution of the Republic of Belarus only establishes, in general language, this subjective possibility for these individual rights. The specifics, however, have to be stipulated through normative legal acts included in the system of legislation of the Republic of Belarus. 


\section{The Constitution of the Republic of Belarus as the basis of the national legal system}

The Belarusian national legal system belongs to the type of Slavic national legal system that emerged from the continental (Romano-Germanic) legal family. The main sources of law in Belarus are normative legal acts, which are formed by lawmaking bodies exercising their law-making power.

A common perspective among Belarusian constitutional law scholars is that that the Constitution forms the basic law of the State, a single codified source of law (Vasilevich, 2019: 5).

The legal literature also defines the Belarusian Constitution as constituting a systematic arrangement of constitutional-legal principles and constitutional-legal norms that regulate social relations that are part of the subject of constitutional law (Chudakov, 1998: 168-169). Constitutional-legal norms and constitutional-legal principles regulate a large sphere of social relations, which include the organization and functioning of state power, its territorial structure, the basis of the legal status of the individual, the individual's relationship with society and the state, and the organization and functioning of local self-government.

The Belarusian Constitution was adopted by the Supreme Council of the Republic of Belarus (at that time the unicameral Belarusian Parliament) on March 15, 1994. It subsequently was amended and supplemented twice. A national referendum on November 24, 1996, resulted in the Belarusian Constitution being changed by almost a third. Changes and additions concerned both the organization and functioning of State bodies and the procedure for altering the Constitution. On October 17, 2004, also at the Republican referendum, amendments were made to Art. 80 of the fundamental law of the Belarusian State, removing the restrictions on the ability of one person to hold the post of President of the Republic of Belarus for only two terms.

The Belarusian Constitution is a modern normative legal act that reflects the current state of public relations, namely, the economic system, social structure, political and ideological spheres of the Belarusian society and State. 
The preamble of the Belarusian Constitution enshrines the notion of national sovereignty, as indicated by the words "We, the People of the Republic of Belarus". The introductory part of the Fundamental Law also defines the fundamental, basic ideals that the Belarusian Parliament, which represents the Belarusian people, relied upon when formulating the provisions of the Constitution. These are the principles of recognition of universal values, of democracy, and the rule of law.

Part 1 of Art. 1 of the Belarusian Constitution declares the Belarusian Republic as a "unitary, democratic, social state based on the rule of law. These characteristics, in fact, are the cornerstone principles upon which the entire Constitution is based.

The Belarusian State in form is a republic. According to Art. 6 of the Basic law, the unified and indivisible state power in Belarus is divided into three distinct branches: legislative, executive, and judicial. According to the constitutional principle of separation of powers, these branches of government are independent, but at the same time have, the ability to mutually influence each other.

The legislative power is represented by the Parliament - the National Assembly of the Republic of Belarus, which is bicameral, meaning that it consists of two chambers. The lower house, the House of Representatives, consisting of 110 deputies, is elected by citizens of the state who have voting rights. The upper house of Parliament, the Council of the Republic, is the chamber of territorial representation and has a more diverse constituency. It consists of 64 members. Eight members of the Council of the Republic are appointed by the President of the Republic of Belarus. Eight members each are elected by the six regional and Minsk city councils of deputies - local representative authorities.

The central body of state administration in Belarus is the Council of Ministers - the Government of the Republic of Belarus. It directs subordinate branches and local executive and administrative bodies. It also is responsible for implementing both the internal and foreign policy of the Belarusian State. Sectoral government bodies ministries and state committees - form and implement state policy in particular areas of public life: the economy, transport, industry, education, and health. 
Judicial institutions are bodies that resolve legal disputes that arise with the participation of citizens, legal entities, state bodies and organizations. The Belarusian judicial system consists of the Constitutional Court of the Republic of Belarus along with courts of general jurisdiction. Courts of general jurisdiction include the Supreme Court of the Republic of Belarus, regional (Minsk city) courts, regional economic courts (Minsk economic court), and district courts. The Constitutional Court is a body of constitutional justice, whose main task is to monitor the constitutionality of normative legal acts. In the exercise of its powers, the Constitutional Court performs its activities in two main forms - preliminary and subsequent constitutional control. In the form of preliminary constitutional control, the Belarusian body of constitutional justice reviews draft laws adopted by the National Assembly of the Republic of Belarus, evaluating them for compliance with constitutional-legal norms and constitutional-legal principles. Follow-up monitoring is aimed at identifying problems of law enforcement practice related to issues of legal uncertainty of legal norms.

The President enjoys a special status in Belarus. According to part 1 of Art. 79 of the Constitution, the President is the Head of State, the guarantor of the Constitution, and of the civil rights and liberties of all of the Belarusian citizens. The President is the highest official of the state and at the same time the highest body of state power does not belong to any of the other branches of government and performs a special role. The President ensures the interaction of state bodies and mediates between them.

The Constitution does not contain a list of republican state administration bodies, but instead uses the general formula "branch state administration bodies". Meanwhile, the constitutional-legal norms and principles fully apply to these institutions-ministries and state committees, by not only defining the foundations of their organization, but also establishing criteria for their effective functioning.

The Ministry of Health of the Republic of Belarus is a republican body of state administration in the Belarusian State that ensures the implementation of a unified state policy in the field of health. It also is responsible for organizing medical assistance to the population, and ensuring the sanitary and epidemic well-being of the population and its drug supply. The Ministry of Health also organizes scientific research in the medical field, coordinates the activities of other bodies and 
organizations, including local executive and administrative bodies in the medical field, and implements other powers assigned to it by the legislation of the Republic of Belarus.

Organizationally, the Ministry of Health includes health departments of regional executive committees - local executive and administrative bodies-and the health committee of the Minsk city executive committee; regional centers of hygiene, epidemiology and public health, Minsk city center of hygiene and epidemiology, city, district, zonal and district centers of hygiene and epidemiology in cities, as well as state organizations subordinate to the Ministry of Health.

\section{The Concept and essence of the constitutional right to health protection}

The right to health protection is one of the constitutional rights in Belarus, enshrined in the Basic law of the Belarusian State. Art. 45 of the Constitution regulates this most important constitutional socio-economic right. According to part 1 of this article, "Citizens of the Republic of Belarus shall be guaranteed the right to health care, including free treatment in at state health-care establishments." (Constitution of the Republic of Belarus, 2004).

One of the key questions in this regard, however, is what exactly is meant by the right to health protection and what does that right encompass. The answer to these questions, in turn, determine the assessment of legislative acts regulating its implementation, as well as the assessment of the State for its sociality and democracy, two of the most important principles of the constitutional structure of the Belarusian State and society.

The issue of the legal parameters of the constitutional right to health protection has not been sufficiently studied in the legal literature. In view of this, the boundaries of this general legal right have been interpreted variably, sometimes even in contradictory ways, thus compromising this protection. 
As suggested by Agievets (Agievets, 2003:15), the right to health care can be defined as set forth in the legislation powers which provide citizens the opportunity to obtain health and other medico-social services in their choice of qualified medical facilities, and to take necessary steps to claim protection in the event of a breach of these rights. According to Otstavnova (Otstavnova, 2011), the right to medical care, which is a component of the more general right to health protection, consists of a number of constituent elements / rights including the right to receive free medical care in state and municipal institutions or in private health care institutions, to receive voluntary medical insurance, preferential prosthetic, orthopedic and dental care, social security with medicines, medical expertise; sanatorium treatment, medical and genetic examination of persons entering into marriage; information regarding health status; the right to be a blood donor and to donate organs and tissues for transplantation, artificial insemination; preventive measures for health protection by the state and the employer, etc. From the point of view of Timofeev (Timofeev, 2017: 112), subsumed within the broad right to health protection and medical care are also the rights to not only affordable but also high-quality medical care. Further, the concept of health protection also includes the rights of preserving health, strengthening health, and restoring health by receiving medical care. Thus, the right to health care is essentially an entire panoply of opportunities related to health, care and treatment, characterized by accessibility and quality.

The wording of the constitutional-legal norm contained in Art. 45 of the Constitution links the right to medical care not only with treatment in health care institutions, including in-state institutions, and provided free of charge, but also with the creation of conditions for medical care accessible to all individuals.

The issue of the essence of the constitutional right to health protection was the subject of consideration by the body of constitutional justice of the Republic of Belarus - the Constitutional Court. Considering the constitutionality of the Law of the Republic of Belarus on amendments and additions to the Law of the Republic of Belarus "On health care" as a mandatory preliminary control, the Belarusian Constitutional Court states in its decision of 5 June 2014 no. R-924/2014 that the right to health protection is "guaranteed in the conditions of the Belarusian state". In explaining its decision, the Constitutional Court made it clear that the general right to health includes free treatment in public health institutions, the creation of conditions for medical care available to all citizens by the state, the development of 
physical culture and sports, adoption by the state of measures to improve the environment, to provide opportunities to use health facilities, and to improve labor protection.

The right to health protection in the Belarus is specified in the Law of the Republic of Belarus on Health Care of June 18, 1993 No. 2435-XII (with amendments and additions) (hereinafter Health Care Law). Art. 4 of this Law emphasizes that the right to health protection encompasses, first of all, the right to affordable medical care. Affordable medical care means, on the one hand, the provision of "free medical care based on state minimum social standards in the field of health in public health institutions", and, on the other hand, the provision of paid medical care. In particular, citizens of Belarus, foreign citizens, and stateless persons can receive medical care from not only state and non-state health organizations, but also from individual entrepreneurs at their own expense, legal entities' funds, and other sources not prohibited by Belarusian law. The state controls the provision of such medical care, since it can only be provided in accordance with the procedure established by law. The right to receive medical care, and the right to health, according to the Health Care Law, includes the availability of medicines and the implementation of measures on sanitary-epidemiological welfare of the population that undergo medical examinations.

The constitutional right to health protection in Belarus is not limited to free medical care in public health institutions and the state system for ensuring the availability of medicines. More broadly, it also includes informed voluntary consent to medical intervention; the choice of the attending doctor and health organization; participation in the choice of methods of medical care; obtaining in an accessible form information about the state of one's own health, the methods used to provide medical care, as well as the qualifications of the attending physician and other medical professionals directly involved in providing medical care; selecting persons who can be informed about the state of one's health; refusing to accept medical care, including medical intervention, except in cases stipulated by law; participation in health organizations whose conditions meet sanitary and anti-epidemic requirements and allow to the patient to exercise the right to safety and protection of personal dignity; and, respectful and humane attitude on the part of health workers. 
The right to health protection is also closely linked to other constitutional rights and freedoms. According to Timofeev (Timofeev, 2019: 23), from the point of view of the constitutional dimension, "human health is a natural condition for the implementation of the rights and freedoms of the individual proclaimed by the Constitution, and therefore, a natural condition for a decent life". Indeed, in accordance with part 1 of Art. 25 of the Belarusian Constitution, the State guarantees the freedom, inviolability and dignity of the individual. Personal dignity is a constitutional value. In another research work, the author highlighted that "respect for the dignity of the individual is the recognition of the right to a decent standard of living. Part 2 of Art. 21 of the Constitution of the Republic of Belarus enshrines the right of everyone to a decent standard of living, including adequate food, clothing, housing and constant improvement of the necessary conditions. The most well - known way to meet your needs at a decent level is to ensure the right to work, the right to rest, the right to housing and the right to education, the right to health and social security" (Shupitskaya, 2018: 33-41).

These studies demonstrate that Belarus has established and operates a sufficiently developed system of normative legal acts regulating the right to health protection. These include constitutional principles and norms, laws adopted by the Parliament, acts of the President of the Republic of Belarus and the Belarusian Government, the Ministry of Health and local authorities.

\section{Normative bases of the right to health protection in the Republic of Belarus}

The legislation of Belarus, bonding the constitutional right to health includes, in addition to the Belarusian Constitution, laws, acts of the President, decisions of the Belarusian Government - the Council of Ministers, normative legal acts of the Ministry of Health, other State bodies, as well as international treaties of the Republic of Belarus.

The Belarusian Constitution is the Fundamental Law of the State and therefore has the highest legal force and heads the hierarchy of the entire system of normative legal acts of the Belarusian State. The Constitution defines the foundations of the constitutional structure of the state and society. As previously discussed, under Art. 1 of the Constitution, Belarus, is a unitary democratic social state ruled by law. These 
are the most significant constitutional-legal principles, among which the following should be mentioned. First, the republican form of government. The Belarusian state is a mixed republic. Also of importance is the unitary nature of the state. Unitarianism assumes that Belarus has a unified system of legislation and a unified system of state bodies, some of which are related to the regulation of public relations in the field of health. Belarus has a unified policy in the sphere of ensuring the health of citizens, which is also determined by the unitary nature of the state. Democracy, as the most important constitutional and legal principle, permeates the internal policy of the state. Sociality focuses on protecting the interests of the individual and supporting the most vulnerable categories of the population. A legal state is a state in which the rule of law, legal law, and the activities of state bodies are related to the implementation of the principle of separation of powers.

The Constitution also contains a provision according to which "man, his rights, freedoms and guarantees for their attainment manifest the supreme goal and value of society and the state", as well as the principles of legality (Art. 2), priority of universally acknowledged principles of international law (Art. 8), and the principle of equality (Art. 22).

The Belarusian Constitution defines the powers of the highest state authorities in all spheres of public life, including health care.

The President of the Republic of Belarus, as the Head of State, ensures the implementation of internal policy in the state, including in the field of health, appoints the Minister of Health, and has the right to issue decrees that are binding on the territory of the state, and in particular, in the sphere of specifying the constitutional right to health protection and how these protections are to be administered.

In accordance with the Basic Law of the Belarusian State, the Parliament, which is the National Assembly of the Republic of Belarus, as a representative and legislative body, adopts laws "on approving the main directions of domestic and foreign policy", "on... health care", "on environmental protection and rational use of natural resources" (Articles 97 and 98 Constitution of the Republic of Belarus). 
The Council of Ministers of the Republic of Belarus - the Belarusian Government - is the central body of state power. It manages the system of subordinate bodies, including the health system. The government ensures the implementation of state policy in the field of health, takes measures to ensure the rights and freedoms of citizens, and implements regulatory legal acts on the territory of the state.

At the local level, the bodies responsible for the health sector are local councils of deputies and executive and administrative bodies - executive committees, administrations and their departments.

The previously mentioned Health Care Law was amended as of October 21, 2016 and consists of 12 chapters, combining 65 articles. The Health Care Law defines the main concepts used in the sphere of legal regulation of health care; basic principles of the state policy in the field of public relations; organization of health care in conditions of the Belarusian State; the rights and obligations of patients and healthcare workers; and, features of providing medical care to certain categories of citizens and issues of providing medicines and other medical products and means to those in need.

The principles of state policy defined by the Health Care Law are industry-specific basic ideas that help to shape the constitutional and legal principles of the Belarusian State and society, such as the principles of justice, equality, and humanism. Thus, the principle of ensuring the availability of medical services, including medicines, is a manifestation of the principle of faimess. The priority of providing medical care for minors, women during pregnancy, childbirth and the postpartum period, disabled people and veterans are expressions not only of the principles of justice and humanism, but also of the constitutional and legal principle of equality. The constitutional and legal principle of proportionality is manifested in the principles of forming a responsible attitude of the population toward the preservation of their health and the responsibility of state bodies and organizations for the health of the population as well as the responsibility of the employer for the health of their employees. 
The Health Care Law also defines the types of medical care provided to individuals within the territory of the Republic of Belarus. These classifications consist of primary medical care; specialized medical care; high-tech medical care; medical and social care; and, palliative medical care.

A special feature of the Health Care Law is that it contains rules regarding the regulation of such issues as changing and correcting gender identity, assisted reproductive technologies, sterilization, artificial termination of pregnancy, and euthanasia.

Among significant legislative acts regulating the right to health protection are also such laws as the Law of the Republic of Belarus of April, 17, 1992 "On veterans"1, the Law of the Republic of Belarus of November 11, 1991 "On social protection of disabled people of the Republic of Belarus" 2 , the Law of the Republic of Belarus of August 1, 2002 "On citizenship of the Republic of Belarus"3, the Law of the Republic of Belarus of June 23, 2008 "On granting foreign citizens and stateless persons refugee status, additional and temporary protection in the Republic of Belarus"4, the Law of the Republic of Belarus of January 4, 2010 "On the legal status of foreign citizens and stateless persons in the Republic of Belarus" 5 , among others.

Legal acts issued by the President also regulate the provision of medical care. Among them, it is necessary to highlight the Decree of the President of the Republic of Belarus dated August 25, 2006 No. 530 "On insurance activities"6.This Decree provides that entities such as the Republic of Belarus, its administrative-territorial units, state bodies, and state legal entities shall insure property interests in the types of insurance related to life insurance only for insurance organizations that are state legal entities. However, the legal entity of the Republic of Belarus and foreign legal entities carrying out activities within the territory of the Republic of Belarus, citizens of the Republic of Belarus permanently residing in the Republic of Belarus, and persons without citizenship must insure their property interests in Belarus only with

\footnotetext{
${ }^{1}$ Law of the Republic of Belarus On veterans of April, 17, 1992.

${ }^{2}$ Law of the Republic of Belarus On social protection of disabled people of the Republic of Belarus of November, $11,1991$.

${ }^{3}$ Law of the Republic of Belarus On citizenship of the Republic of Belarus of August, 1, 2002.

${ }^{4}$ Law of the Republic of Belarus On granting foreign citizens and stateless persons with refugee status, additional and temporary protection in the Republic of Belarus of June 23, 2008.

${ }^{5}$ Law of the Republic of Belarus On the legal status of foreign citizens and stateless persons in the Republic of Belarus of January, 4, 2010.

${ }^{6}$ Decree of the President of the Republic of Belarus On insurance activities of August, 25, 2006.
} 
commercial organizations established for conducting insurance activity and having special permits (licenses) to conduct insurance activities in the Republic of Belarus, unless otherwise established by the President.

As mentioned above, the Ministry of Health plays a key role in ensuring the constitutional rights of Belarusian citizens to health protection. It has the power to issue regulations specifying constitutional-legal principles and constitutional-legal norms in the field of health care. Thus, the Decree of the Ministry of Health dated May 7, 2009 No. 49 "On approval of the Instruction on the procedure for mandatory medical examination of foreign citizens and stateless persons applying for refugee status or additional protection in the Republic of Belarus"7 defines the procedures for mandatory medical examinations of foreign citizens and stateless persons applying for refugee status or additional protection in the Republic of Belarus.

Resolution of the Ministry of Health of August 12, 2016 No. 96 "On approval of the Instructions on the procedure for conducting medical examinations" 8 approved the procedure for conducting medical examinations of adults and children in the Republic of Belarus. In accordance with the above-mentioned Instructions, dispensary medical examinations and dispensary monitoring are conducted in Belarus. The examination includes medical services related to the health check ${ }^{9}$ and the required medical interventions. Dispensary monitoring is a medical monitoring of the state of the health of citizens, depending on the group of that is the subject of the monitoring. Under this system, medical examinations are conducted by health care institutions that provide medical care in outpatient conditions at the place of residence, place of work, place of study, as well as other health organizations. According to the Instructions, these medical examinations are performed directly by district internists, district pediatricians, general practitioners, and other specialist doctors.

\footnotetext{
${ }^{7}$ Decree of the Ministry of health of the Republic of Belarus of May, 7, 2009 No 49 On approval of the Instruction on the procedure for mandatory medical examination of foreign citizens and stateless persons applying for refugee status or additional protection in the Republic of Belarus.

${ }^{8}$ Resolution of the Ministry of Health of the Republic of Belarus of August 12, 2016 on approval of the Instructions on the procedure for conducting medical examinations.
} 
Local authorities and administrations are also among the state bodies whose activities are related to health. Accordingly, the decisions of local authorities and administrations are also intended to regulate the issues of health protection of citizens living in a certain territory. So, for example, from April 1, 2020 on the territory of the city of Grodno (Republic of Belarus) the decision of the Grodno city executive committee, a local government body, has entered into force, approving a plan of measures to prevent and reduce the spread of acute respiratory infections, including those caused by coronavirus. ${ }^{10}$ This plan includes measures such as preventing employees with signs of respiratory infections from working This plan also stipulates that employees who arrived from abroad before the expiration of their self-isolation period could not work. Organizations of all forms of ownership are obligated to conduct wet cleaning using disinfectants at least once a day and to air the premises as often as possible. The plan also requires that public places shall be equipped with dispensers with antiseptics, liquid soap, and, if necessary, personal protective equipment. This decision also mandates all trade workers to wear medical masks and disposable gloves. The decision recommends that all persons in shopping facilities observe a social distance of at least one meter. In catering facilities, tables are requested to be placed at a distance of at least 1.5 meter apart. Exhibitions, presentations, fairs and other indoor events were canceled in the city; sports, cultural, entertainment and other events were restricted. Discos have been suspended, and sports and fitness halls, reading rooms, and libraries have been restricted. Hookah smoking is prohibited in public catering facilities.

\section{State, problems and perspectives of realization of the right to health protection in the modern Belarusian state}

The state health care system in Belarus is based on the principles of justice, equality, humanism, and other important constitutional-legal principles.

The health care system is funded through the state budget. Currently, there are about 600 healthcare organizations that provide medical care in inpatient settings and about 1,500 outpatient organizations; 17 state-owned research and practice centers; 143 centers of hygiene and epidemiology; more than three thousand pharmacies; and, 134 emergency medical stations (Health care in Belarus, 2020). The health care

\footnotetext{
${ }^{10}$ Decision of the Grodno city executive committee of March 31, 2020 on establishing an action plan. Plan for the prevention and reduction of acute respiratory infections, including those caused by COVID-19 coronavirus.
} 
system consists of four levels, ranging from paramedic and midwifery centers to national research and practice centers.

The following are state-owned scientific and practical centers that exist in the country: "Cardiology", "Mother and child", "Organ and tissue transplantation", "Neurology and neurosurgery", "Transfusiology and medical biotechnologies", "Traumatology and orthopedics" and others (Health care in Belarus, 2020). These centers provide a close link between science and practice, without which there would not be so many new technologies introduced into the treatment and diagnosis of diseases.

The health systems of only three post-soviet countries outside the European Union were ranked in the top 50 most effective in the world - Belarus, Georgia and Russia. The Republic of Belarus ranks 40th in this international ranking, scoring 40.6 points out of 100 possible; Georgia-45th (38.3 points), Russia - 50th (37.6 points) (Belarusian medicine, 2020).

The undoubted advantage of the Belarus health care system is the special attention the state pays to the move vulnerable segments of the population - children, women with children, and the disabled. Today, Belarus is among the top 50 countries in the world in terms of pregnancy management and delivery by qualified medical personnel.

One of the important aspects of implementing the right to medical care in Belarus is creating conditions for surrogacy. Surrogacy is a type of assisted reproductive technology. In August 2006, for the first time in the Republic of Belarus, the possibility of concluding a surrogacy contract was established at the legislative level.

Another area of public importance relates to the development of human tissue and organ transplantation. In this sphere, the Republic of Belarus strictly respects the freedom, inviolability and dignity of a person. Moreover, the inviolability and right to privacy in the sense of self-control are guaranteed to the individual even upon death. The implementation of these rights in the field of transplantation is ensured by the following norms established by the Law of the Republic of Belarus of March 4, 1997 No. 28-Z "On human organ and tissue transplantation". Human organs and (or) tissues may not be the subject of civil transactions, except for transactions that 
are gratuitous. Making paid transactions, as well as advertising the demand and (or) offers of human organs and (or) tissues are prohibited (part 4 of Art. 5 of the Law). Organ collection from a living or deceased donor and transplantation may be performed only by state health organizations in accordance with the procedure established by the relevant legislative acts (Art. 6 of the Law). As living donors according to Art. 7 of the Law, only the recipient's spouse or close relative can act. The living donor must be provided with a written warning about the possible health risks associated with the procedure. Organs and tissues may be taken from presumptive the donor only following the donor's voluntary, written consent which must be properly notarized (Art. 8 of the Law). Consent to the collection of organs can be withdrawn at any time before the start of the collection of organs (part 2 of Art. 9 of the Law). A more problematic issue concerns the question of consent to transplantation after death. The Belarusian legislator has taken the path of presuming an individual's consent to take organs and tissues for the purpose of transplantation survives the donor's death. The procedure will not be carried out only if a written statement of disagreement on the selection of organs for transplantation is submitted to the health organization after the death of a capable citizen (Art. 10-1 of the Law).

As in any country, the Republic of Belarus has certain problems related to ensuring citizens' right to health protection. These include lengthy waiting lists to receive in clinics, workload of doctors, insufficient prestige of the profession, and the lack of development of insurance medicine.

Minimization and elimination of these problems will contribute to increasing the constitutional right to health protection. ,Improvement of public health indicators based on further improvement of the quality of medical services, the provision of unified social standards of medical care for everyone, regardless of their place of residence, the expansion of the use of high-tech equipment and information technologies through increased public investment in healthcare, the development of public-private partnerships, expanding the range of paid medical services (while maintaining the possibility of receiving the necessary treatment on a free basis) will also help to achieve this goal. The long-term tasks of Belarus in the sphere of public health also include developing preventive measures such as methods promoting citizens' healthy lifestyles, providing high-quality and affordable medical care, and ensuring the sanitary and epidemic well-being of the population. Achieving these goals will go along way toward preserving the foundations of the state health system 
and protecting the constitutional rights of citizens to health protection It also is critical to strengthen the responsibility of executive bodies of the state at all levels in order to implement all areas of state health policy. Lastly, both state entities (organs of the state) and citizens themselves must work together in a partnership to better ensure the health of all Belarusian citizens.

\section{$6 \quad$ Conclusions}

Constitutional and legal principles and norms comprise the legal bases of the right to health protection in the Republic of Belarus. Detailed regulation of this most important constitutional right is effectuated at the level of normative legal acts of the Republic of Belarus adopted by various state bodies. Protecting the health of citizens is a critical area of activity of the Belarusian State, and is constantly the focus of its attention. This is a consequence of the development of sociality as one of Belarusian's significant constitutional and legal principles.

\section{References}

Agievets, S. V. (2003) Medicinskoe pravo: uchebnoe posobie (Grodno: Grsu).

Alexandrova, O. Yu. (2006) Otvetstvennost' za pravonarusheniya v medicine: uchebnoe posobie dlya stud. vyssh. ucheb. Zavedenij. (Moscow: Academy).

Azarov, A.V. (2007) Obespechenie $i$ zashchita prav graz̧hdan pri okazanii medicinskoj pomoshchi I (Moscow: Geotar-Media).

Belorusskaya medicina $-v$ tope samyh effektivnyh $v$ mire, retrieved from www.mpt.gov.by/ru/trade-unionnews/belorusskaya-medicina-v-tope-samyh-effektivnyh-v-mire (27 July 2020).

Chudakov, M. F. (1998) Konstitucionnoe gosudarstvennoe pravo zarubez̧hny stran (Minsk: Harvest).

Murgel J. (2020) Medical Negligence and Liability of Health Professionals in the European Court of Human Rights Case Law, Medicine, Law \& Society, 13(1), pp. 21-44.

Otstavnova, Yu. A. (2011) Konstitucionnye osnovy zashchity prava cheloveka i graz̧hdanina na obranu zdorov'ya $i$ medicinskuyu pomoshch' v sovremennoj Rossii: avtoreferat dis. kand. nauk (Saratov).

Shupitskaya, A. N. (2018) Chelovecheskoe dostoinstvo i konstitucionnye principy, Vesnik of Yanka Kupala State University of Grodno. Series 4. Jurisprudence, 8(1), pp. 33-41.

Timofeev, I. V. (2017) Pravo i medicina: konstitucionno-pravorye, organizacionnye voprosy dostupnosti $i$ kachestva medicinskoj pomoshchi (Saint-Petersburg: DNA Publishing house).

Timofeev, I.V. (2019) Dostupnost' i kachestvo medicinskoj pomoshchi: konstitucionn-pravovoe ižmerenie. (SaintPetersburg: DNA Publishing House).

Vasilevich, G.A. (ed.). (2019). Konstitucionnoe pravosudie: uchebnoe posobie (Minsk: Higher School).

\section{Legal acts}

Constitution of The Republic of Belarus [Electronic resource]: [with ed. and add., adopted at the REP. referendums 24 Nov. 1996, 17 Oct. 2004] [Electronic resource]/ Etalon. Legislation of the Republic of Belarus/ National center for legal information. Rep. Belarus. - Minsk, 2020. 
On approval of the Instruction on the procedure for mandatory medical examination of foreign citizens and stateless persons applying for refugee status or additional protection in the Republic of Belarus: Resolution of the Ministry of Health of the Republic of Belarus of May 7, 2009 №. 49 [Electronic resource]/ Etalon. Legislation of the Republic of Belarus/ National center for legal information. Rep. Belarus. - Minsk, 2020.

On approval of the "Regulations on the procedure for payment of monetary remuneration to the donor for the provision of their germ cells by a health organization that has collected donor germ cells", "Regulations on the procedure for creating and maintaining a unified register of germ cell donors": Resolution of the Council of Ministers of July 13, 2012 No. 643 [Electronic resource]/ Etalon Legislation of the Republic of Belarus/ National center for legal information. Rep. Belarus. - Minsk, 2020.

On citizenship: Law of the Republic of Belarus of 1 Aug. 2002 no. 136-ZB in ed. Law of the Republic of Belarus of July 20, 2016, No. 414-Z [Electronic resource]/ Etalon Legislation of the Republic of Belarus/ National center for legal information. Rep. Belarus. - Minsk, 2020.

On compliance with the Constitution of the Republic of Belarus of the Law Of the Republic of Belarus "On amendments and additions to the Law of the Republic of Belarus "On healthcare": Decision of the Constitutional Court of the Republic of Belarus of June 5, 2014 no. R924/2014 [Electronic resource]: http://www.kc.gov.by/document-36513. (27 July 2020).

On establishing an action plan. Plan for the prevention and reduction of acute respiratory infections, including those caused by COVID-19 coronavirus: Decision of the Grodno city executive committee of March 31, 2020 No. 232 [Electronic resource]: http://grodno.gov.by/ru/main.aspx?guid=2691 (30 July 2020).

On granting refugee status, additional and temporary protection to foreign citizens and stateless persons: Law of the Republic of Belarus of June 23, 2008 No. 354 [Electronic resource]/ Etalon. Legislation of the Republic of Belarus/ National center for legal information. Rep. Belarus. - Minsk, 2020.

On health care: Law of the Republic of Belarus of June 18,1993. No. 2435-XII, as amended on October 21, 2016 No. 433-Z [Electronic resource]/ Etalon. Legislation of the Republic of Belarus/ National center for legal information. Rep. Belarus. - Minsk, 2020.

On human organ and tissue transplantation: Law of the Republic of Belarus No. 28-Z of March 4, 1997, ed. Law of the Republic of Belarus of June 18, 2019 No. 199-Z [Electronic resource]/ Etalon. Legislation of the Republic of Belarus/ National center for legal information. Rep. Belarus. - Minsk, 2020.

On insurance activity: Decree of the President of the Republic of Belarus of August 25, 2006, N 530b in ed. of Decree of 18. 06. 2009 No. 323 [Electronic resource]/ Etalon. Legislation of the Republic of Belarus/ National center for legal information. Rep. Belarus. - Minsk, 2020.

On measures to implement the Decree of the President of the Republic of Belarus of August 25, 2006 No. 530: Resolution of the Council of Ministers of the Republic of Belarus of November 4, 2006 No. 1462b in the ed. of the Resolution of the Council of Ministers of the Republic of Belarus of June 3, 2020 No. 327 [Electronic resource]/ Etalon. Legislation of the Republic of Belarus/ National center for legal information. Rep. Belarus. - Minsk, 2020.

On social protection of disabled people in the Republic of Belarus: law of the Republic of Belarus from November 11, 1991 No. 1224-XII, with ed. and additional amendments made by the law of the Republic of Belarus of July 17, 2009 No. 48-Z [Electronic resource]/ Etalon. Legislation of the Republic of Belarus/ National center for legal information. Rep. Belarus. - Minsk, 2020.

On the legal status of foreign citizens and stateless persons in the Republic of Belarus: Law of the Republic of Belarus of January 4, 2010 No. 105-Z, in ed. Law of the Republic of Belarus of December 16, 2019 No. 267-Z [Electronic resource]/ Etalon. Legislation of the Republic of Belarus/ National center for legal information. Rep. Belarus. - Minsk, 2020.

On the procedure for payment of monetary remuneration to a germ cell donor and the unified register of germ cell donors: Resolution of the Council of Ministers of the Republic of Belarus of July 13, 2012 No. 643 with amendments of the Resolution of the Council of Ministers of the 
Republic of December 26, 2019, No. 916 [Electronic resource]/ Etalon. Legislation of the Republic of Belarus/ National center for legal information. Rep. Belarus. - Minsk, 2020.

On veterans: law of the Republic of Belarus of April 17, 1992 No. 1594-XII, as amended by the Law of the Republic of Belarus of January 9, 2017 No. 15-Z [Electronic resource]/ Etalon. Legislation of the Republic of Belarus/ National center for legal information. Rep. Belarus. Minsk, 2020. 
